\title{
Spatial Distribution of Schistosomiasis Foci on Itamaracá Island, Pernambuco, Brazil
}

\author{
CS Barbosa ${ }^{+}$, KC Araújo, L Antunes*, T Favre**, OS Pieri**
}

Laboratório de Esquistossomose, Centro de Pesquisas Aggeu Magalhães-Fiocruz, Av. Moraes Rego s/nº, Cidade Universitária, 50670-420 Recife, PE, Brasil *Departamento de Engenharia Cartográfica, UFPE, Recife, PE, Brasil **Laboratório Ecologia e

Controle de Moluscos Vetores, Instituto Oswaldo Cruz-Fiocruz, Rio de Janeiro, RJ, Brasil

Acute cases of schistosomiasis have been found on the coastal area of Pernambuco, Brazil, due to environmental disturbances and disorderly occupation of the urban areas. This study identifies and spatially marks the main foci of the snail host species, Biomphalaria glabrata on Itamaracá Island. The chaotic occupation of the beach resorts has favoured the emergence of transmission foci, thus exposing residents and tourists to the risk of infection. A database covering five years of epidemiological investigation on snails infected by Schistosoma mansoni in the island was produced with information from the geographic positioning of the foci, number of snails collected, number of snails tested positive, and their infection rate. The spatial position of the foci were recorded through the Global Positioning System (GPS), and the geographical coordinates were imported by AutoCad. The software packages ArcView and Spring were used for data processing and spatial analysis. AutoCad 2000 was used to plot the pairs of coordinates obtained from GPS. Between 1998 and 20025009 snails, of which 12.2\% were positive for S. mansoni, were collected in Forte Beach. A total of 27 foci and areas of environmental risk were identified and spatially analyzed allowing the identification of the areas exposed to varying degrees of risk.

Key words: schistosomiasis - spatial distribution - vectors control - Global Positioning System - Pernambuco - Brasil

Schistosomiasis is historically endemic in the rural areas of Pernambuco with the rate of human infection varying from 12 to $82 \%$ in some localities (Favre et al. 2001). The prevalence and intensity of infection in affected communities are geared to the leisure or domestic practices relevant to each locality (Barbosa et al. 1998, Moza et al. 1998, Pieri et al. 1998).

Human cases of acute infection have recently been detected in beach resorts where the disease is being introduced due to the disorderly occupation of urban areas. The lack of work in the country side causes a rural exodus to the coastal tourist areas and infected individuals contaminate the freshwater habitats of the host snails found in those areas.

New sites of active transmission of the disease are being detected in beach resorts where the fluctuating population of holidaymakers are subjected to infection, principally after the rainy season (Barbosa et al. 1998, Barbosa \& Pieri 2000). Recently, the beach resort of Porto de Galinhas, in the southern coastal area of Pernambuco, suffered an outbreak and 410 acute cases of schistosomiasis was registered (Barbosa et al. 2001).

In the 1980's a vast area of mangrove in Itamaracá Island, located in the northern coastal area of Pernambuco, was filled in to build summer condominiums, without any

${ }^{+}$Corresponding author. Fax: +55-81-3453.1911. E-mail: cbarbosa@cpqam.fiocruz.br

Received 28 May 2004

Accepted Infected system of rain-water drainage. As a result, freshwater swamps were formed in the lowlands and became colonized by host snails which were eventually infected with miracidia from the faeces of the workers originally from rural endemic areas. These swampy habitats overflow in the rainy months carrying the infected snails to the streets and into the houses, thus infecting both holiday makers and residents (Barbosa \& Pieri 2000).

Details of the environmental conditions which interfere with the health of the population can be shown on maps which depict the spatial distribution of the risk areas (Carvalho et al. 2000) enabling epidemiologists to understand the spatial dynamics of the disease. The spatial questions related to the health-disease process have been increasingly studied by geographers and epidemiologists (Andrade 2000).

An important instrument being used in the analysis of health situations is the Geographic Information System - GIS (OPAS 1996) making use of computer technology to spatially analyse a large amount of information within a geographic context (Vine et al. 1997). It allows inputting, saving, organizing, analyzing, displaying, and reporting geographically referred data (Sanson et al. 1991). The inputs are from the collection of spatial data, maps, and other information related to the population obtained by accessing different datadases, by phototopographic survey and remote sensors. The data is then transformed into information in the form of thematic maps, graphs, and table (OPAS 2002), making it possible to plan, analyse, manage, and monitor the spatial data (Najar \& Marques 1998).

Digital cartography facilitates the selection of data for interpreting a specific problem and the use of multivariable analysis which are associated with environmental factors, social, and physical, with diseases (Andrade 2000). 
The techniques of spatial analysis are determined by the nature of the data collected (Bailey 2001) and the final result is the choice of an inferential model which explicitly considers the spatial relationship present in the phenomenon (Câmara et al. 2000).

The study of the patterns of geographic distribution of the diseases and their relation to the socio-environmental factors of risk is the object of Geographic Epidemiology, which employs increasingly sophisticated statistical methods of analysis (Shimakura et al. 2001).

This spatial study describes a potential hazard to health, identifying groups exposed to risk of infection and contributing to the surveillance and monitoring of the health of specific populations. To achieve this, a sofware using GIS for identifying and locating schistosomiasis foci in Praia do Forte, Itamaracá Island, was developed. It used digital cartography to pinpoint the position of the foci and spatially highlighted the areas of biological and environmental risks.

\section{METHODOLOGY}

The study area was Praia do Forte, in Itamaracá Island (Pernambuco), situated $47.5 \mathrm{~km}$ to the north from the city of Recife and frequented by holiday makers and tourists in the summer season. Malacological surveys carried out in the area identified infected Biomphalaria glabrata snails, thus indicating active transmission of the disease where acute human cases had been recorded (Gonçalves et al. 1992). The records of this study contained valuable data on the number of snails collected and number of snails infected by Schistosoma mansoni, per year and per site of collection.

The units of analysis were the identified transmission foci with their localization and spatial position. The inclusion variables were the number of snails collected and the number of infected snails from 1998 to 2002.

Physical and topographic maps of Itamaracá Island (Fidem 2001) kept on magnetic media were used as cartographic bases. The spatial database containing the graphic elements was obtained from the following topographic data: blocks, lots, buildings, and toponymies.

The spatial location of the foci was determined by instant positioning collected from a GPS (Global Positioning System) apparatus. The coordinates were determined on a Universal Transverse Mercator (UTM) projection system and with reference to the SAD69 datum. The attributes were entered and organized in an electronic spreadsheet.

The Autocad program was used to analyse the data through the following stages: (i) conversion of the GPS coordinates to the cartographic base; (ii) editing of the graphic elements by selecting the topographic data needed in the study; (iii) generating information plans; and (iv) adjustment of the toponymy.

Processing of the spatial data was carried out by importing the archives generated in the various stages of analysis. ArcView was used to establish topological relationships between the graphic elements and the respective attributes. In this way it was possible to carry out the spatial analyses and visualise them through thematic maps. Another way of obtaining the results was from the
Table. One of the great advantages of GIS is that the spatial database, once created, can be constantly updated thus permitting the monitoring of events with time.

The program SPRING, developed by the National Institute of Spatial Research in Brazil (Inpe) and freely distributed, was used to interpolate and calculate the approximate value of altitude using the following mathematical model:

$\mathrm{d}=\left[\left(\mathrm{x}-\mathrm{x}_{0}\right)^{2}+\left(\mathrm{y}-\mathrm{y}_{0}\right)^{2}\right]^{1 / 2}, d=$ Euclidian distance between the interpolation point and its surrounding $\mathrm{i}$, $w(x, y)=(1 / d)^{u=1} u=$ exponent of the weighing function.

$$
f(x, y)=\frac{\left(\sum_{1}^{0} W(x, y)\right)^{*} z}{\left(\sum_{1} W(x, y)\right.}
$$

where: $w(x, y)=$ weighing function and $f(x, y)=$ function of interpolation

On the basis of the features associated to each focus identified in Praia do Forte, a model of spatial dependence was drawn up making it possible to interpolate the surface represented on the maps year by year and for the whole period of study (1998-2002). This interpolation generated a pattern for the distribution of the zones where the risk potential for transmission of schistosomiasis mansoni varied from light to heavy.

\section{RESULTS}

The results of the snail survey are shown in (Table). During the period 1998 to 2002,5009 snails were collected with $12.2 \%$ positive for $S$. mansoni. The rate of natural infection varied from $4.3 \%$ to $28.8 \%$ during this period. In the post-winter season of 2000, when there were exceptionally heavy rains, 289 out 2784 snails collected in the flooded areas were positive. This indicated a potential risk of contamination for people walking on the streets in the area at that time.

The base of the spatial data of Praia do Forte was generated from the graphic data and added data from ArcView. A total of 27 foci of schistosomiasis were identified and mapped from the GPS coordinates, (Fig. 1) shows the streets and the blocks, which are essential for identifying the extra-domiciliary foci, the buildings, for the intra-domiciliary foci, and the freshwater habitats. The descriptive data shown on the maps are the street toponymy, the number of snails collected, the number of positive snails, and the rate of snail infection per focus for every year of the study. Together these make up a very important source of epidemiological information which can be used in the planning and control actions.

The photograph (Fig. 1) shows a temporary puddle of water on the crossroad at Araras Street. The volume of water extends up to the pavement and walls of the building indicative of an extra-domiciliary focus. The spatial database system shows photographs which illustrate and highlight special features and situations at risk.

Fig. 2 shows the blocks 1 to 11 which are connected to Araras Street. The areas at major environmental risk are in blocks 5,7 , and 10 where 3,1 , and 2 foci respectively were recorded. This information, recorded in the spatial database, is indicative of extra- and intra-domiciliary foci found along the main access paths to the beach. 


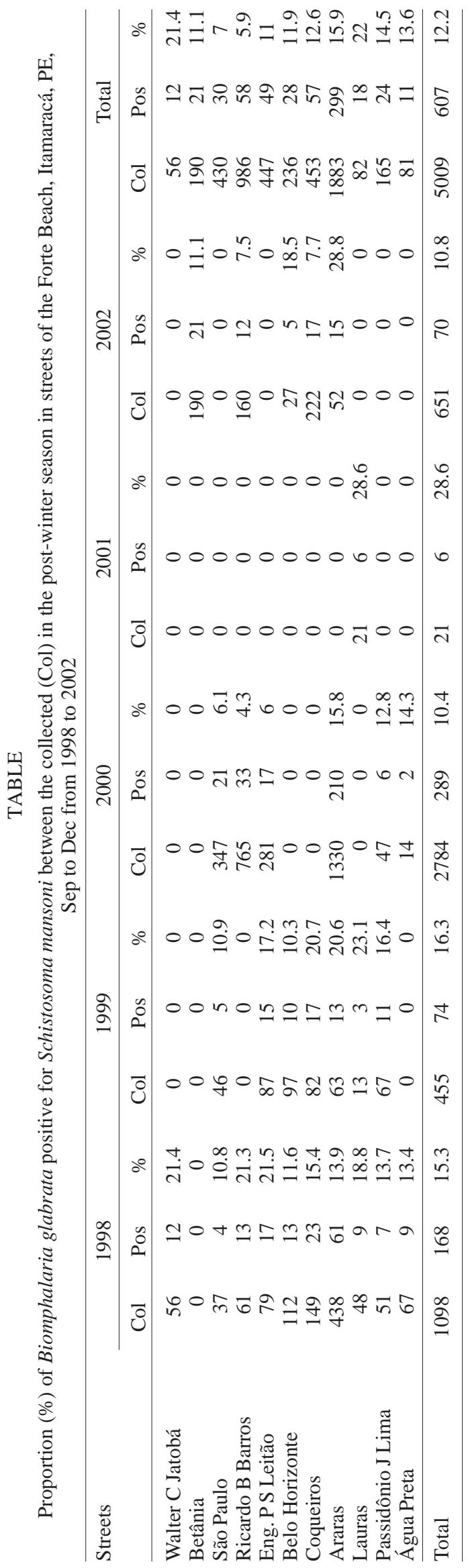

A year by year comparison shows the unequal distribution of the endemic disease characterized by the intermittent presence of the focus interspersed in areas with the occurrence of isolated cases. As the information obtained in the period 1998-2002 (Fig. 3) was superimposed it was possible to show that the potential of moderate risk predominated in the greater part of Praia do Forte, followed by high risk. However, zones of low risk were not identified.

\section{DISCUSSION}

The results from the snail survey show that the rate of B. glabrata infection had an annual variation from $10.4 \%$ to $28.6 \%$ and, on common land, from $4.3 \%$ to $28.8 \%$. This characterizes a major potential risk for schistosomiasis transmission in the post-winter months coinciding with the large number of tourists and holiday makers on the island.

The epidemiological study carried out on the Itamaracá Island in 1997 (Barbosa \& Pieri 2000) stated that the rate of natural infection of snails varied from $7.9 \%$ to $20.5 \%$ and that, in the summer months, $18.6 \%$ of the snails collected from ponds on the access roads to the beach were positive for S. mansoni. The authors confirmed that transmission of schistosomiasis on the island may occur all year round with greater risks of infection after the rainy season.

The present study confirms that the large number of snails collected during 2000 represented more than 50\% of the total number of snails collected and almost $50 \%$ of positives.

The investigations carried out during 1998 and 2002 reiterate the importance of extra- and intra-domiciliary foci in the transmission of schistosomiasis on Itamaracá Island.

The patterns of spatial distribution revealed that the dynamics of schistosomiasis transmission cannot be statistically analyzed, but within the context where it occurs. This shows the importance of the social aspects of space occupation where transmission occurs.

According to Barbosa and Pieri (2000) the disorderly occupation of space on Island Itamaracá, not counting the destruction of the original ecosystem, creates the ideal environmental conditions for the establishment of countless breeding places for the host snails in areas favouring human infection. The use of clay for infilling and levelling of land favours the maintenance of different breeding habitats with variable quantities of snails during the year. This contributes to the unequal distribution of schistosomiasis as seen by the presence of spatial units with differential risks. Data from IBGE (1998) regarding sanitation measures taken in Itamaracá Island stated that 34.5\% of the houses had inadequate water supply and $100 \%$ of these had precarious sanitary system. On Praia do Forte it is common to see molluscs living in streams, next to houses, into which sewer or overflow from cesspits discharge. This is an ideal scenario for the continual maintenance of the foci.

The system developed in this work will allow the health services to monitor the foci detected by GIS, confirming useful information in epidemiological surveillance. The 
methods of spatial analysis accurately complement the investigation on the pattern of distribution of localized events. According to Bergquist (2001), the development of the GIS models in projects which involve climatic varia- tions and drainage of water contributes to better documentation and thus decision making which could avoid the increase in transmission as well as the appearance of epidemics in areas previously non endemic.

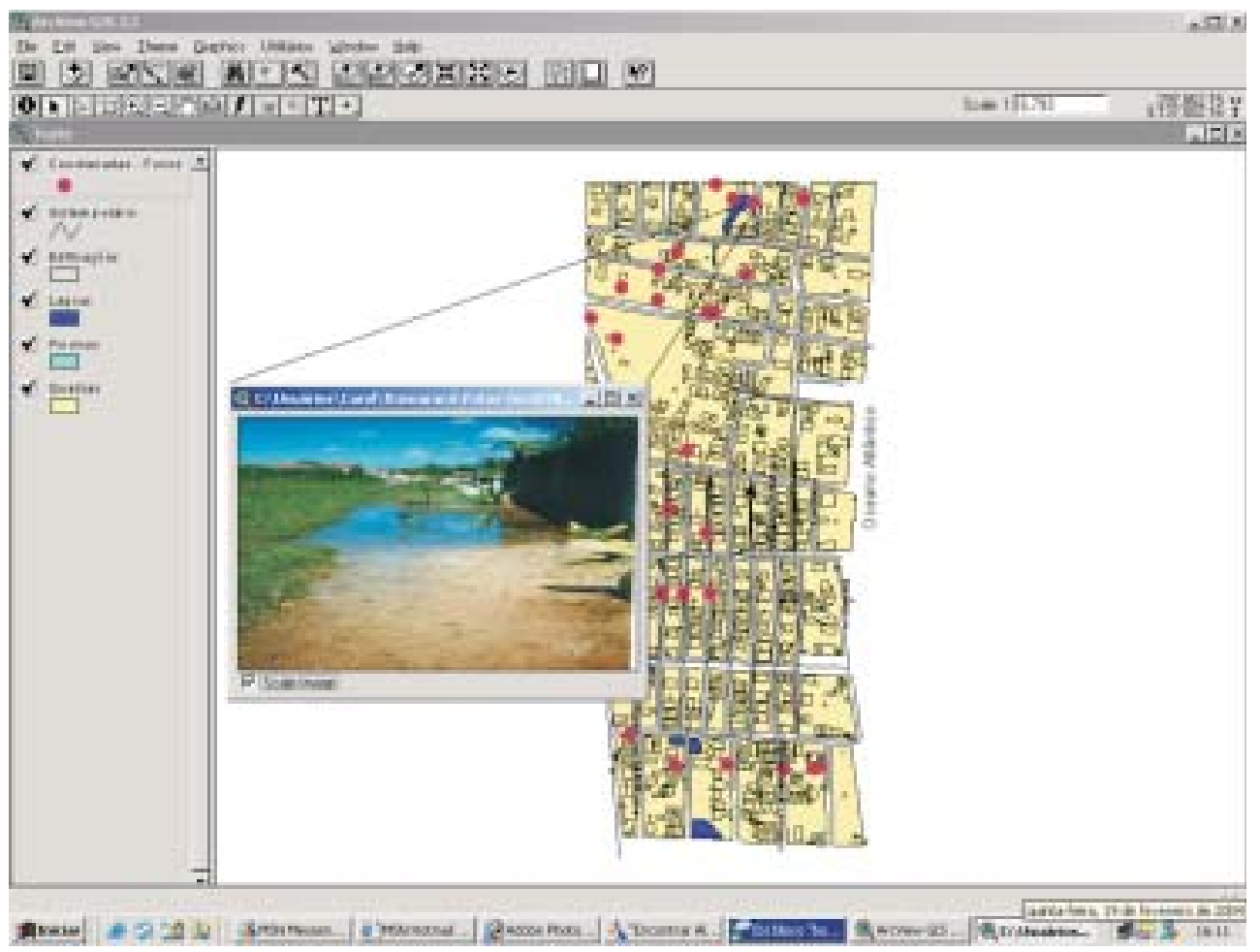

Fig. 1: thematic map of the Forte Beach with an extra-domiciliary focus

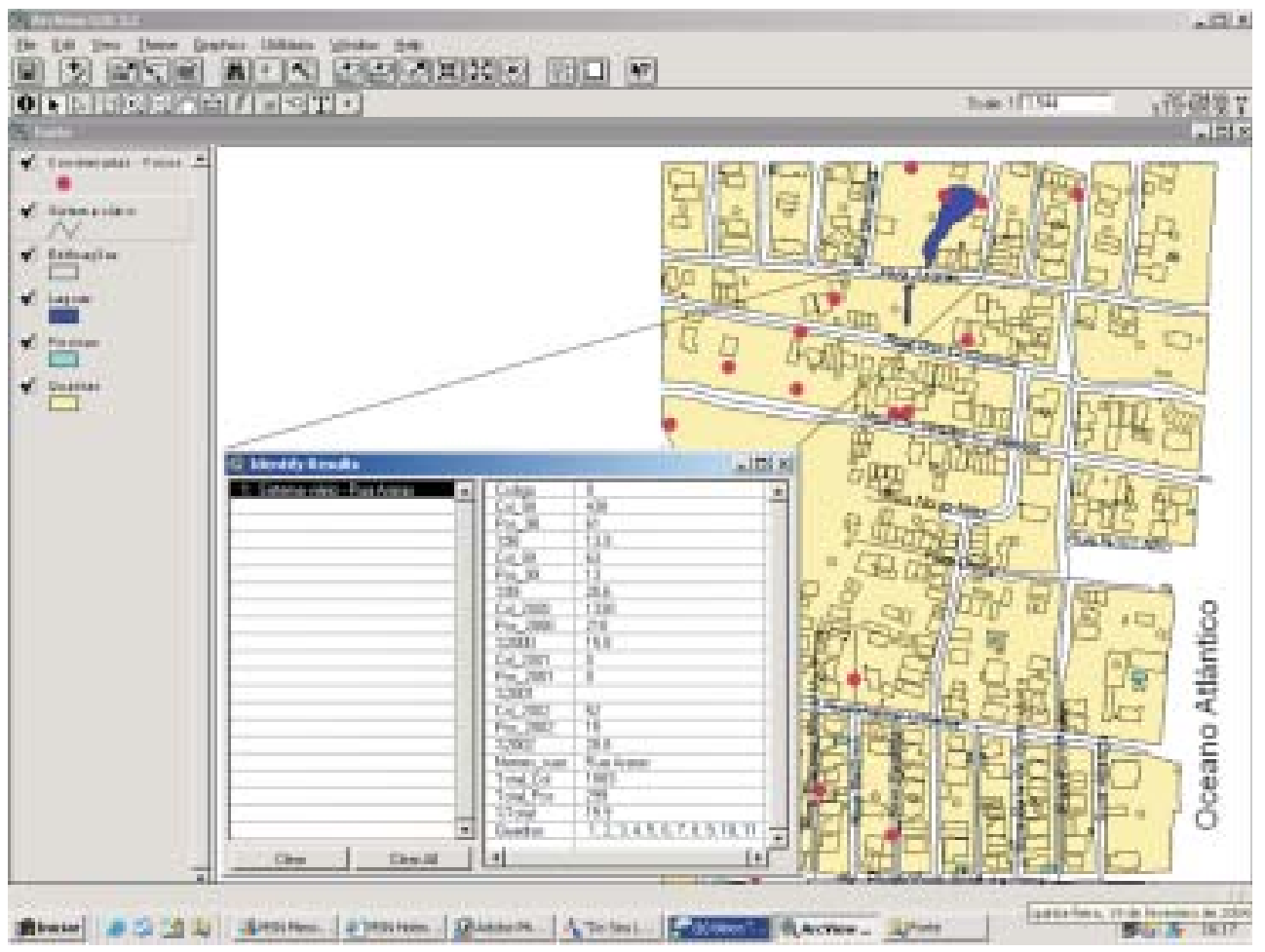

Fig. 2: thematic map of the Forte Beach with areas at major environmental risk 


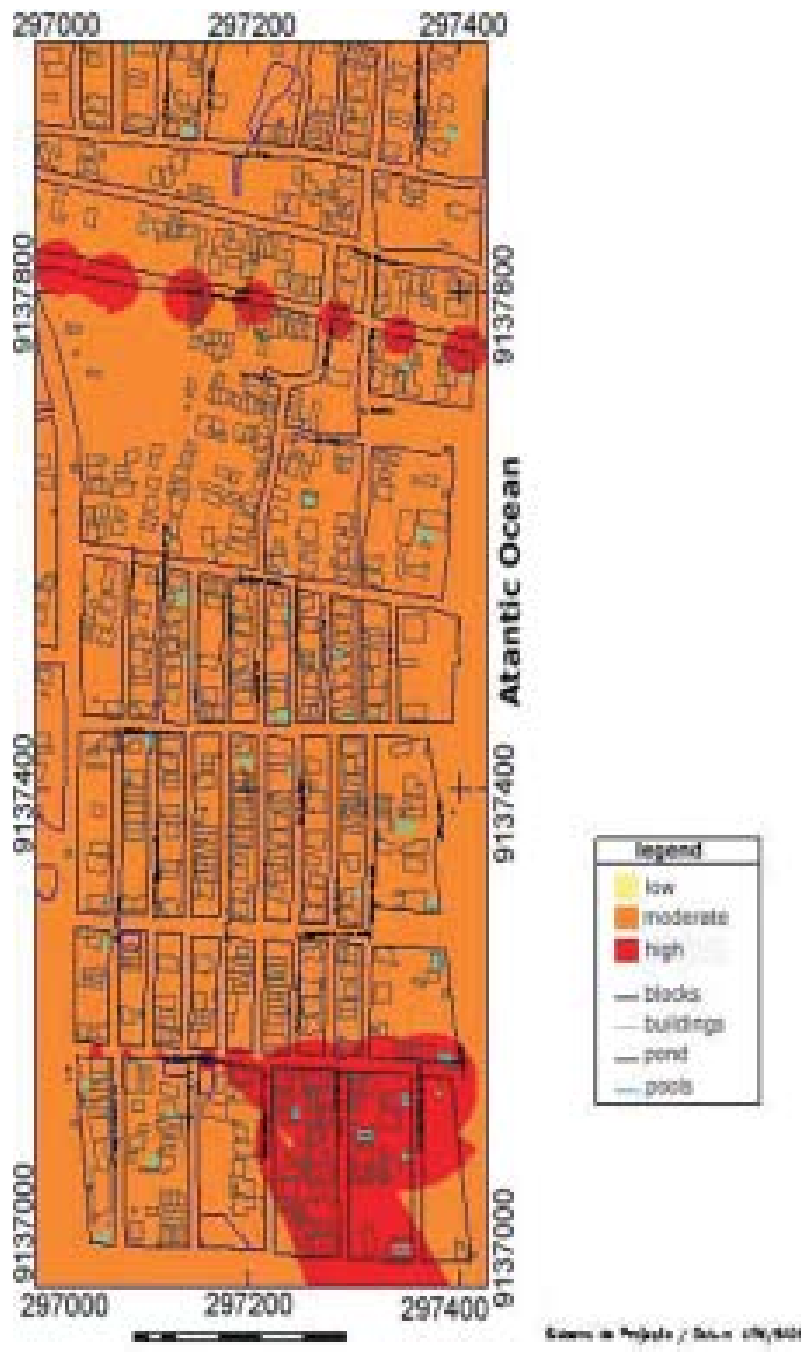

Fig. 3: risk potencial for transmission of schistosomiasis mansoni in Forte Beach, Itamaracá Island between 1998 and 2002

\section{ACKOWLEDGMENTS}

To the technicial staff of Serviço de Referencia para Diagnóstico em Esquistossomose do CPqAM-Fiocruz, for the valuable help in work at the laboratory and in the field.

\section{REFERENCES}

Andrade MEB 2000. Geografia médica: origem e evolução. In RB Barradas, Doenças Endêmicas: Abordagens Sociais, Culturais e Comportamentais, Fundação Oswaldo Cruz, Rio de Janeiro, p. 151-166.

Bailey TC 2001. Spatial statistical methods in health. Cad Saúde Públ 17: 1083-1098.

Barbosa CS, Pieri OS 2000. Aspectos epidemiológicos e malacológicos da esquistossomose mansônica na Ilha de Itamaracá, Pernambuco. Rev Saúde Públ 34: 33-41.

Barbosa CS, Coutinho AL, Montenegro SML, Abath F, Spinelli V 2001. Epidemia de esquistossomose aguda na praia de Porto de Galinhas, Pernambuco. Cad Saúde Públ 17: 725728.

Barbosa CS, Gonçalves JF, Albuquerque Y, Barbosa FS 1998. Urban schistosomiasis im Itamaracá island, Brasil: epidemiological factors involved in the recent endemic process. Mem Inst Oswaldo Cruz 93: 265-266.

Bergquist NR 2001. Vector-borne parasitic diseases: new trends in data collection and risk assessment. Acta Trop 79: 13-20.

Câmara G, Davis C 2000. Arquitetura de Sistemas de Informação Geográfica. In G Câmara, C Davis, AM Monteiro (org.), Introdução à Ciência da Geoinformação, http://www. dpi.inpe.br/gilberto/livro/introd.

Carvalho MS, Pina MF, Santos SM 2000. Conceitos Básicos de Sistemas de Informação Geográfica e Cartografia Aplicados à Saúde, Organização Panamericana de Saúde, Ministério da Saúde, Brasília, DF.

Favre T, Pieri O, Barbosa CS, Beck L 2001. Avaliação das ações de controle da esquistossomose implementadas entre 1977 e 1996 na área endêmica de Pernambuco, Brasil. Rev Soc Bras Med Trop 34: 569-576.

Fidem-Fundação de Desenvolvimento Municipal 2001. Perfil Municipal. Ilha de Itamaracá, Pernambuco.

Gonçalves F, Coutinho A, Santana W, Barbosa CS 1992. Esquistossomose aguda de caráter episódico, na Ilha de Itamaracá, Estado de Pernambuco, Brasil. Cad Saúde Públ 7: 424-425.

IBGE-Instituto Brasileiro de Geografia e Estatística 1998. Saneamento, Itamaracá, Pernambuco.

Moza PG, Pieri OS, Barbosa CS 1998. Fatores sócio-demográficos e comportamentais relacionados à esquistossomose em uma agrovila da zona canavieira de Pernambuco, Brasil. Cad Saúde Públ 14: 107-115.

Najar AL, Marques EC 1998. Saúde e Espaço: Estudos Metodológicos e Técnicas de Análise, Fundação Oswaldo Cruz, Rio de Janeiro.

OPAS 1996. Uso de los sistemas de información geográfica en epidemiología (SIG-EPI). Bol Epidemiol 17: 1-6.

OPAS 2002. Sistema de Informação Geográfica em Saúde: Conceitos Básicos, Organización Panamericana de la Salud, Brasilia, DF.

Pieri OS, Barbosa CS, Moza PG 1998. Schistosomiasis control based on repeated chemotherapy in a rural village of the sugar-cane zone in Northeast Brazil. Mem Inst Oswaldo Cruz 93: 259-264.

Sanson RL, Pfeiffer DV, Morris RS 1991. Geographic information systems: their application in animal disease control. Rev Sci Tech 10: 179-195.

Shimakura SE, Carvalho MS, Aerts DRG, Flores R 2001. Spatial risk distribution: modeling infant mortality in Porto Alegre, Rio Grande do Sul State, Brasil. Cad Saúde Públ 17: 1251-1261.

Vine MF, Degnan D, Hanchette C 1997. Geographic information systems: their use in environmental epidemiologic research. Environ Health Perspect 105: 598-605. 
